\title{
The Status of Black Woodpecker in Northern Tohoku District, Japan"
}

\author{
Ko Ogasawara*, Yuichi Izumi**, and Tadashi Fujii***
}

\begin{abstract}
The nesting, roosting, and feeding trees of Black Woodpeckers (Dryocopus martius) were investigated in natural mature beech forests for clarifying the current geographical distribution of Black Woodpeckers at Aomori, Akita, and Iwate Prefectures in the northern Tohoku District, Japan. Home range sizes of the Black Woodpecker investigated were determined based on the distribution of field signs (new and old nesting, roosting, and feeding trees) in beech forests on Mt. Moriyoshi, and Mt. Oppu of the Shirakami area, especially during the breeding seasons. The area of natural beech forests in the study areas of the above mentioned three prefectures occupied about 370,600 ha. A home range size (HRS) was about 1,000 ha. Distribution range (DR) was about 64,000 ha in size, and the available range (AR) for the woodpecker was about 23,000 ha. By dividing the areas of DR and AR by HRS, the population size of Black Woodpecker was estimated to be 174 birds in the northern Tohoku District.
\end{abstract}

Key words: Black Woodpecker, Northern Tohoku District, Home range, Estimated population size.

\section{Introduction}

The genus Dryocopus consists of only two species in Japan; the Black Woodpecker (Dryocopus martius) and White-bellied Black Woodpecker (Dryocopus javensis richards). The former is restricted to Hokkaido and the northern Tohoku District, while the latter restricted to Tsushima Island may already be extinct based on the fact that no bird has been recorded since 1920. The Black Woodpecker prefers natural mature beech forests (Fagus crenata) throughout its ranges of the northern Tohoku District, such as Mt. Moriyoshi, Akita Prefecture (Ogasawara 1988), and the Shirakami area, Aomori Prefecture (Ogasawara 1990). Furthermore, Ohno \& Chiba (1979) observed an adult with a fledgling in the beech forest near the Towada Lake. However, little has been known about their status in detail.

The survey on the present status of this endangered species in the Tohoku District is important for promoting its protection. Therefore, we have researched the field signs of Black Woodpecker in beech forests of the northern Tohoku District, until present time, since we and a staff member of Akita Yachono-Kai found newly a nest with three nestlings in Mt. Moriyoshi of Honshu, Japan, at 21st May 1978.

An additional study was made on home range size of the Black Woodpecker in breeding habitats of the beech forest at the two areas of Mt. Moriyoshi, and Mt. Oppu, the

\footnotetext{
Received 21 May 1992, Revised 21 September 1992, 2nd Revision 1 December 1993, 3rd Revison 7 March 1994, Accepted 22 April 1994.

1) A part of this research was supported by the Grant-in-Aid for Co-operative Research (A) (Project Number: 01102001) in the Ministry of Education, Science and Culture.

* Department of Biology, College of Education, Akita University, Tegata Gakuencho, Akita, 010 Japan.

** Akita Health Center, Akita Prefectural Office, Nakadori, 2-1-52, Akita, Japan.

*** Tsugaruishi Junior High School, Ohsawa 1-14, Yamada Town, Iwate, Japan.
} 


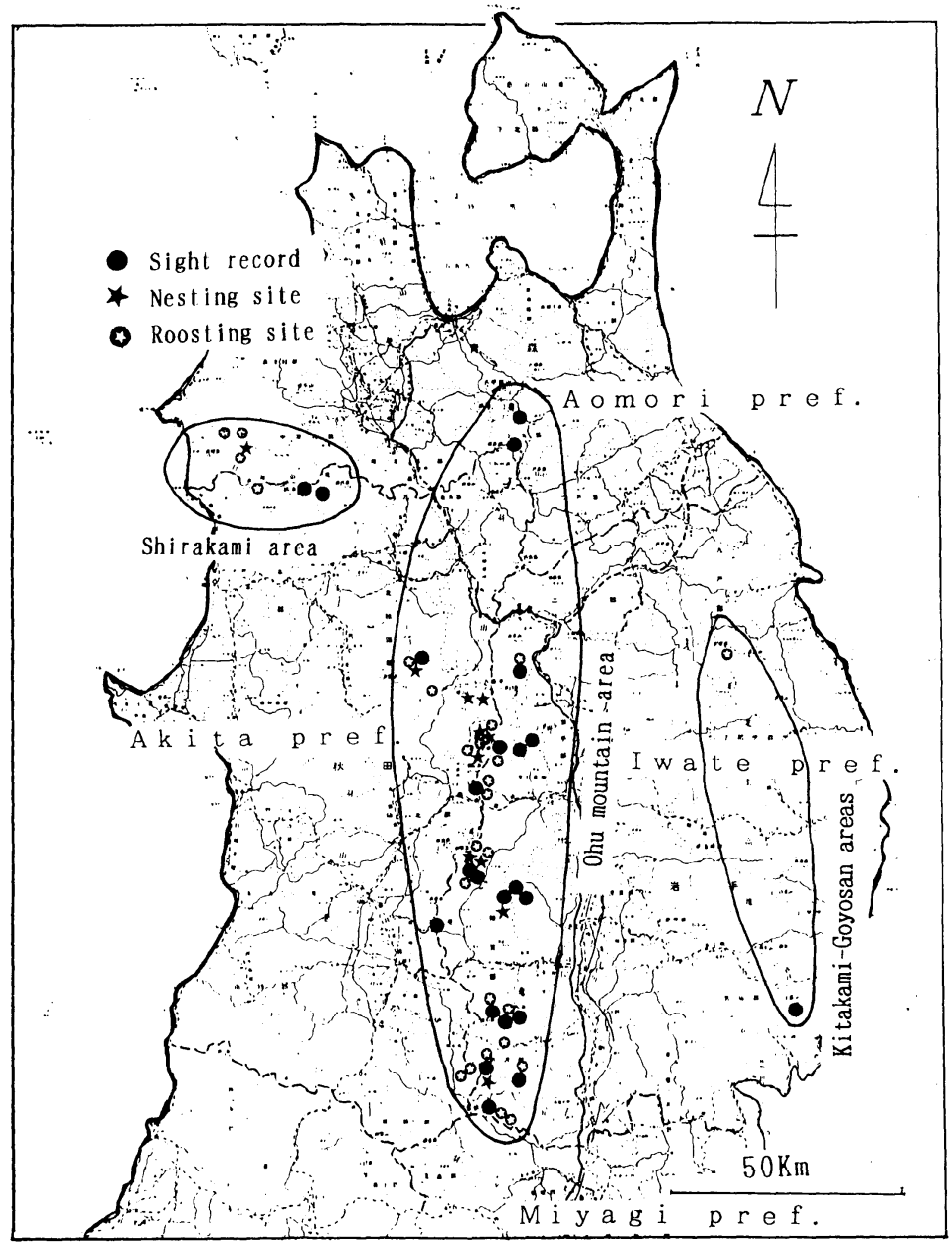

Fig. 1. Showing the records of adult Black Woodpecker $(\boldsymbol{O})$, nesting tree $(\star)$, and roosting tree $(\boldsymbol{\bullet})$ in the northern Tohoku District (Aomori, Akita, and Iwate Prefectures) in 1989.

Shirakami area, and on the available range (the beech forest area in which Black Woodpecker is inhabitable, judging from many field signs of this species) and the population size of Black Woodpeckers in Aomori, Akita, and Iwate Prefectures in the northern Tohoku District.

\section{Study Area}

The study areas were the Shirakami area and the Towada-Hakkoda area, Mt. Hachimantai, Mt. Moriyoshi, Mt. Nyuto, Mt. Kurikoma, Busugamori, and Mt.Kurikoma in the northern Tohoku District.

As the field signs were found mainly in the beech forests of Aomori, Akita, and Iwate 


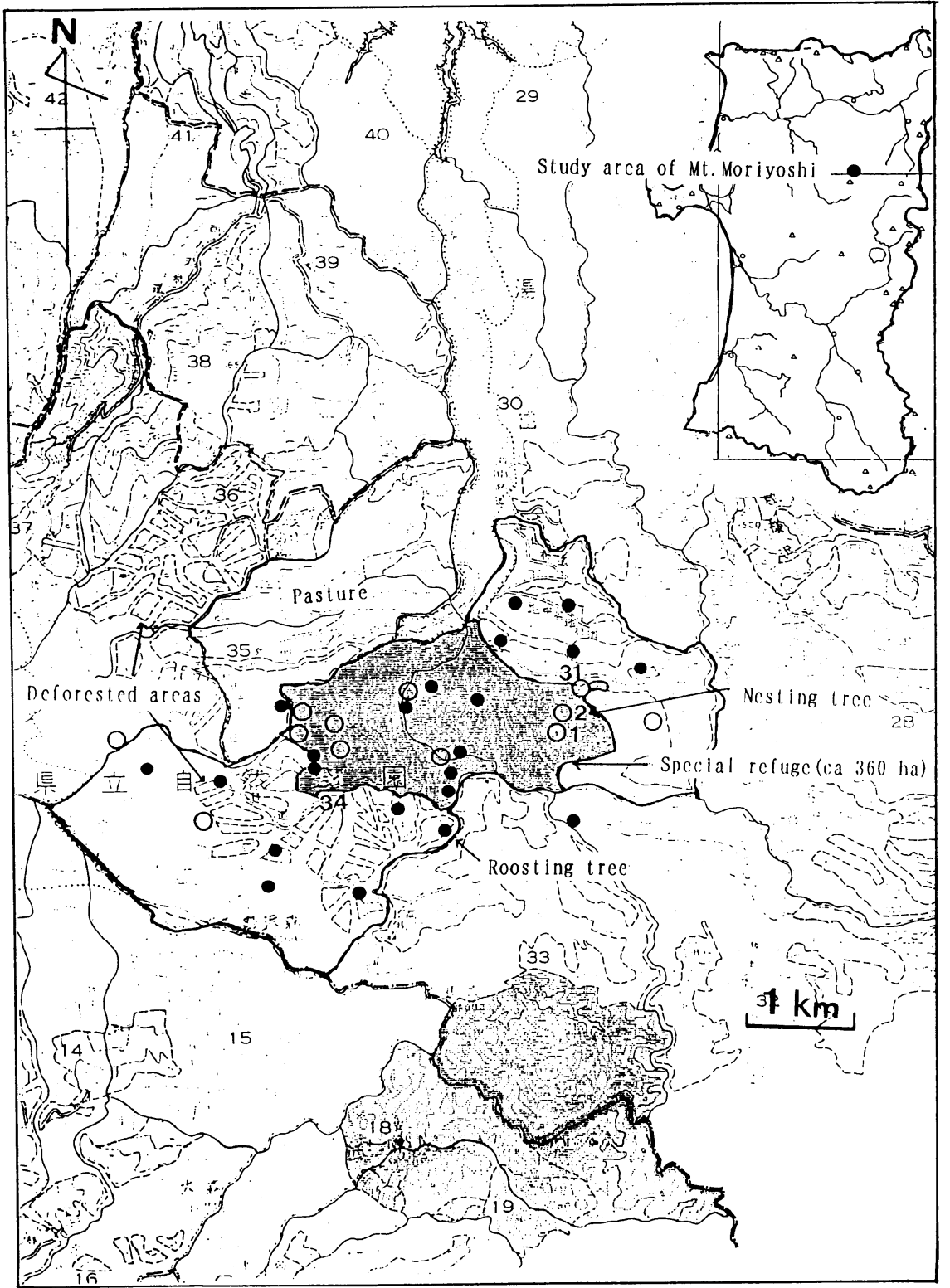

Fig. 2. A distribution map (home range) including the nesting and roosting sites of Black Woodpecker in the beech forest at Mt. Moriyoshi, 1978. Nesting tree $(\bigcirc)$. Numerical numbers are shown the nesting trees from 1987 to 1980 . Roosting trees (O). Figures show Block number (Rinpan by Forestry Office).

Prefectures, three areas, the Shirakami area, the Ohu mountain area, and Mt. Kitakami, were investigated intensively (Fig. 1).

Furthermore, the home range size (HRS) was measured at Mt. Moriyoshi from 1976 
to 1980 and at Mt. Oppu in the Shirakami area from 1990 to 1992.

The size of the study area of Mt. Moriyoshi was about 2,000 ha including the Blocks 31 and 34 (31 and 34 Rinppan) in beech forest (Fig. 2).

All these areas are predominated by beech forests including the nesting, roosting, and feeding trees of Black Woodpeckers.

\section{Study Method}

The field signs such as nesting, roosting, and feeding trees were recorded on $1 / 50,000$ or 1/25,000 topographical maps as evidences indicating the occurrence of Black Woodpeckers. Nest and roost holes having the following characteristics were designated as those of the species. The nest hole was similar to a hen's egg in shape with an average diameter of about $15 \times 12 \mathrm{~cm}$, and the nests were located from 6 to $15 \mathrm{~m}$ above the ground. The roosting hole has similar characteristics of the nest hole, and some of them were usually found in more large trees.

However, the Black Woodpecker has frequently used the nest holes for roosting, especially during the non-breeding season (Ogasawara 1990).

It is a little difficult to distinguish the feeding marks of Black Woodpeckers from those of other species of woodpeckers, except for large feeding holes deeply bored on the underpart of big standing trees in mid-winter. These feeding marks are made for feeding on borer ants (Ogasawara \& Izumi 1978).

Several investigators searched the field signs of the Black Woodpecker in beech forests from late April to early December 1976 and 1980.

We also measured the home range size of a pair of Black Woodpecker in the beech forest of Mt. Oppu in the Shirakami area, 1990 and 1992, with support of the Nature Conservation Society of Japan (NACS-J). Investigators with transceiver were placed at the several favorable observation points in the beech forest for tracing the movement of the pair. Locations of nest trees, roost trees, and new feeding trees, and several trees with

Table 1. Records of Black Woodpeckers from Akita and Aomori Prefectures at the recent years.

\begin{tabular}{l|l|l|l}
\hline \hline \multicolumn{1}{c|}{ Areas } & Year & \multicolumn{1}{|c}{ Records } & \multicolumn{1}{|c}{$\begin{array}{c}\text { Investigators and personal } \\
\text { communication unpublished }\end{array}$} \\
\hline Moriyoshi & 1978 & First breeding in Honshu & \multicolumn{1}{|c}{ Akita Yachono Kai (1978) } \\
Ogasawara \& Izumi \\
Akaishi river in the Shirakami & 1983 & Roosting trees & Y. Izumi \\
Akaishi river in the Shirakami & 1989 & Old roosting tree & Y. Izumi \\
Kushiisidaira in the Shirakami & 1989 & Old roosting tree & Y. Izumi \& K. Ogasawara \\
Akaishi river in the Shirakami & 1990 & Nest & Kouichi Kamada \\
Komagadake in the Shirakami & 1989 & Feeding male & Tomio Nagasaki \& Reiichi Sekiya \\
Tashirodake in the Shirakami & 1989 & Feeding male \& female & Hirosaki Forestry Bureau \\
Oppu in the Shirakami & 1990 & Nest & K. Ogasawara \& Y. Izumi \\
Tamagawa in Hachimantai & 1989 & Old roosting tree & Y. Izumi \\
Tamagawa in Hachimantai & 1989 & Old roosting tree & K. Ogasawara \& Y. Izumi \\
Nyuto & 1989 & Old roosting tree & Ohno \& Chiba (1979) \\
Towada & 1979 & Parent with fledgling & Hisamatu \\
Tsuta Spa in Hakkoda & 1989 & Adult & Y. Izumi \& K. Ogasawara \\
Kurikoma & 1986 & Old roosting trees &
\end{tabular}




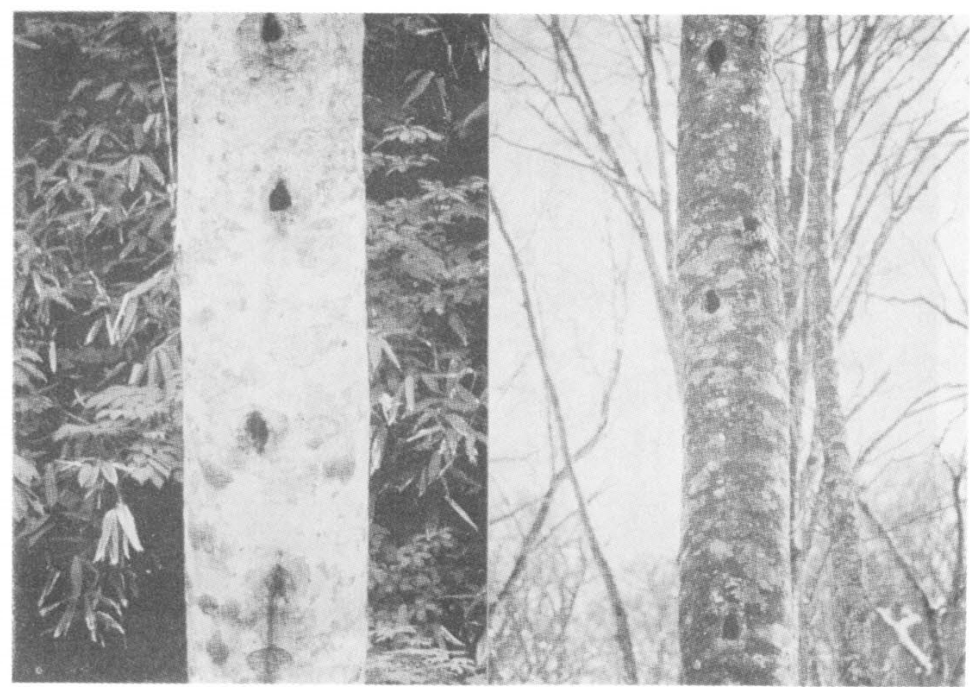

Photo 1. Roosting trees near the small river of Osawa in Mt. Hachimantai

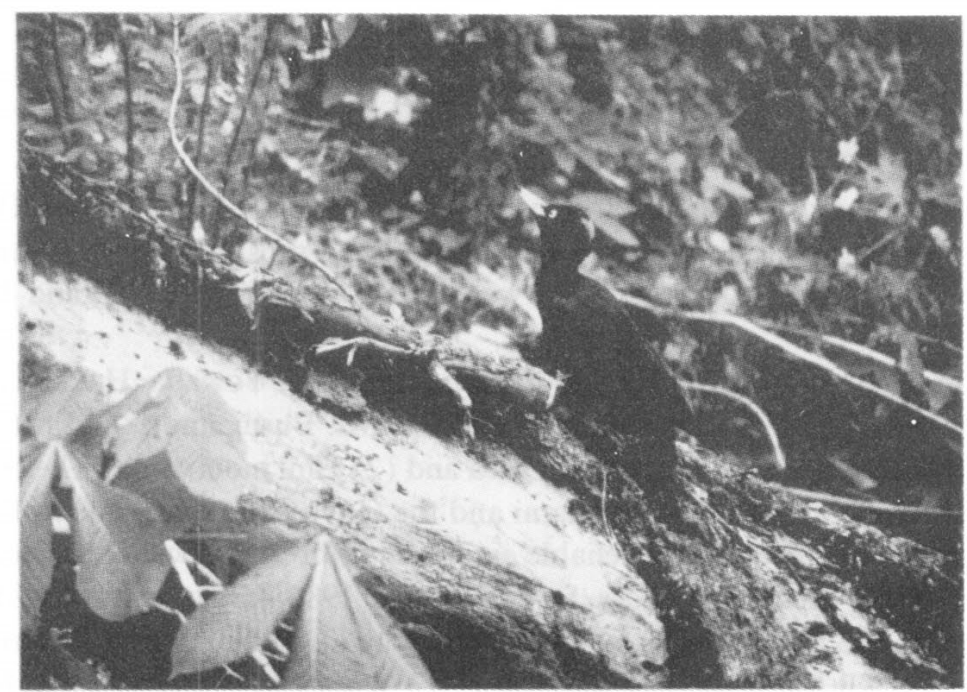

Photo 2. A feeding female of Black Woodpecker at Mt. Tashiro-Dake in Mt. Shirakami area. (Photo by Akita Sakigake News peper Co. LTD. May 1989).

small new holes for nesting were recorded in a topographical map with $250 \mathrm{~m}$ mesh. These field signs should be marked by this species.

We have surveyed intensively many fields signs of Black Woodpeckers in the beech forests of the northern Tohoku District (Aomori, Akita and Iwate Prefectures) with support of many investigators from 1989 to 1990 . Furthermore, we made efforts to take pictures of field signs and feeding Black Woodpeckers, and fortunately used some pictures 


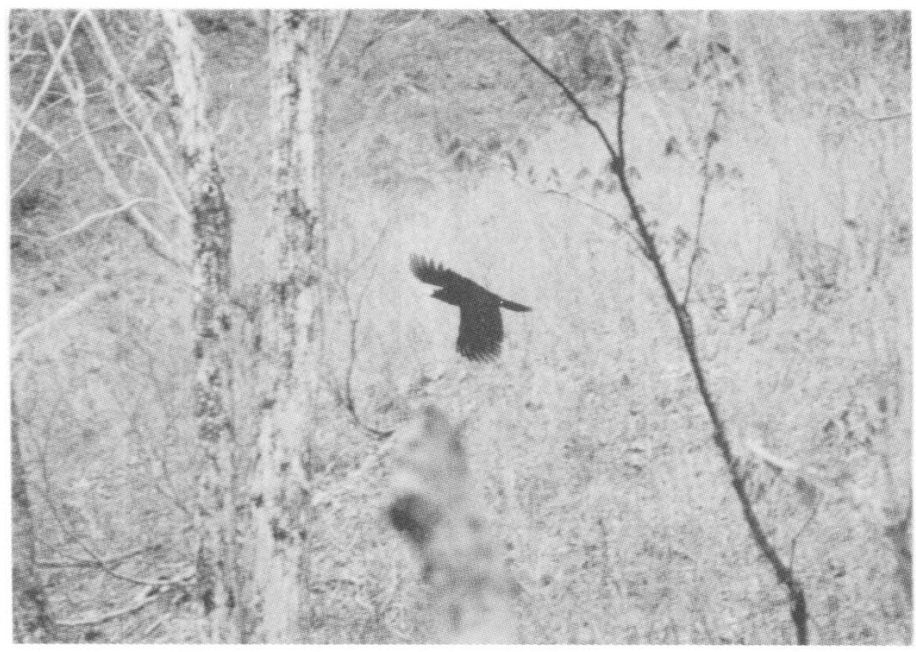

Photo 3. A flying male of Black Woodpecker at Mt. Tashiro-Dake in Mt. Shirakami area. (Photo by Mr. Tomio Nagasaki, 7 May 1989)

of the feeding Black Woodpeckers taken by bird watchers.

\section{Results}

1) Recent records of Black Woodpeckers from the northern Tohoku District.

Many records of Black Woodpecker's breeding, roosting, feeding, and sighting locations in the northern Tohoku District were obtained mainly in 1989 and 1990 (Table 1).

The main distribution areas such as the Shirakami and Towada-Hakkoda areas, Mt. Hachimantai and Mt. Moriyoshi, Mt. Mahirudake, Mt. Busugamori, and Mt. Kurikoma are grouped into two areas; (1) Shirakami area and (2) Ohu mountains. The beech forests remained only small areas in Mt. Kitakami and the Goyosan area, because of cutting off.

Among the three records, the reliable evidences of breeding were obtained from Mt. Moriyoshi in three successive years from 1978 to 1980 (Ogasawara 1988), near the Akaishi River at the Shirakami area, in 1989 and 1990, and at Mt. Oppu from 1990 to 1992 (Table 1). All the breedings were observed from early May to early July in each year.

In addition to the breeding records at the Shirakami area, there were some sight records and photographs taken by Mr. Koichi Kamada at Mt. Komagadake, Fujisato village, and by Mr. Tomio Nagasaki at Mt. Tashirodake, Tashiro town, Akita Prefecture (Table 1). These photographs are also important evidences indicating the inhabitation of this species in these areas. One photographer, Mr. Reiichi Sekiya (Akita Sakigake News Paper Co. LTD), also observed a female feeding on a fallen tree in beech forest near Mt. Tashirodake, on the 15th and 16th May 1989 (Photo 2), and a male flying around the same feeding site, on the 7th May 1989 (Photo 3 ). 
Table 2. The areas of the natural beech forest (ha), the distribution range, and the available range in each mountainous area.

\begin{tabular}{l|c|c|c}
\hline \multicolumn{1}{c|}{ Name of mountain area } & $\begin{array}{c}\text { Total amount of } \\
\text { natural beech forest }\end{array}$ & $\begin{array}{c}\text { Distribution range } \\
\text { (DR) }\end{array}$ & $\begin{array}{c}\text { Available range } \\
\text { (AR) }\end{array}$ \\
\hline Shimokita Penin. & 6,700 & \\
Tsugaru Penin & 13,900 & 5,000 & \\
Towada-Hakkoda area & 55,400 & 30,000 & \\
Shirakami area & 57,200 & & 2,000 \\
Mt. Kitakami & 13,000 & 19,000 & 5,000 \\
Mt. Hayachine & 2,000 & & 10,000 \\
Mt. Hachimantai \& Mt. Moriyoshi & 66,000 & & 1,000 \\
Mt. Taiheizan & 27,700 & & 5,000 \\
Mt. Mahiru & 28,000 & 10,000 & 23,000 ha \\
Mt. Busugamori & 21,000 & & \\
Mt. Kurikoma & 40,700 & 64,000 ha & \\
Mt. Hinoto \& Mt. Chokai & 39,000 & & 87,000 ha \\
\hline \multicolumn{1}{c}{ Total } & 370,600 ha & & \\
\hline
\end{tabular}

The beech forest occupies only an area of about 370,600 ha in the above mentioned three prefectures of the northern Tohoku District (Table 2); 57,200 ha in the Shirakami area, 55,400 ha in Towada-Hakkoda, 66,000 ha in Hachimantai and Moriyoshi, 28,000 ha in Mt. Mahirudake, 21,000 ha in Mt. Busugamori, 40,700 ha in Mt. Kurikoma, 39,000 ha in Mt. Hinoto and Chokai. However, no record of the Black Woodpecker has been obtained from Shimokita and Tsugaru Peninsulas and Mt. Hinoto-Chokai (Table 2).

2) HRS in two breeding habitats.

The home range size of the Black Woodpeckers was measured at two breeding habitats; Mt. Moriyoshi, and Mt. Oppu in the Shirakami area.

(1) Home range size in Mt. Moriyoshi.

The locations of nest and roost trees are plotted on the topographical map (Fig. 2).

There were many feeding trees in the beech forests of the Blocks 31 and 34 and their surrounding areas.

The distribution area of both new and old nests and roost trees (Fig. 2) was about 1,000 ha and thought to coincide a home range of this pair in 1978 to 1980 . In fact, we could frequently observed woodpeckers feeding in these Blocks and their surrounding areas.

An area of two Blocks (31 and 34) extended about 1,000 ha. However, unfortunately the government forestry office cut out some parts of the beech forest in Blocks 34, 35, and 36 (Fig. 2).

An area of about 360 ha of Black Woodpecker's habitat has remained as a special government refuge within Blocks 31 and 34 (Fig. 2). This remaining area for a pair of this species is too small to inhabit and breed.

(2) HRS in Mt. Oppu.

An example of the movements of a female which nested at Mt. Oppu in 1991 was 


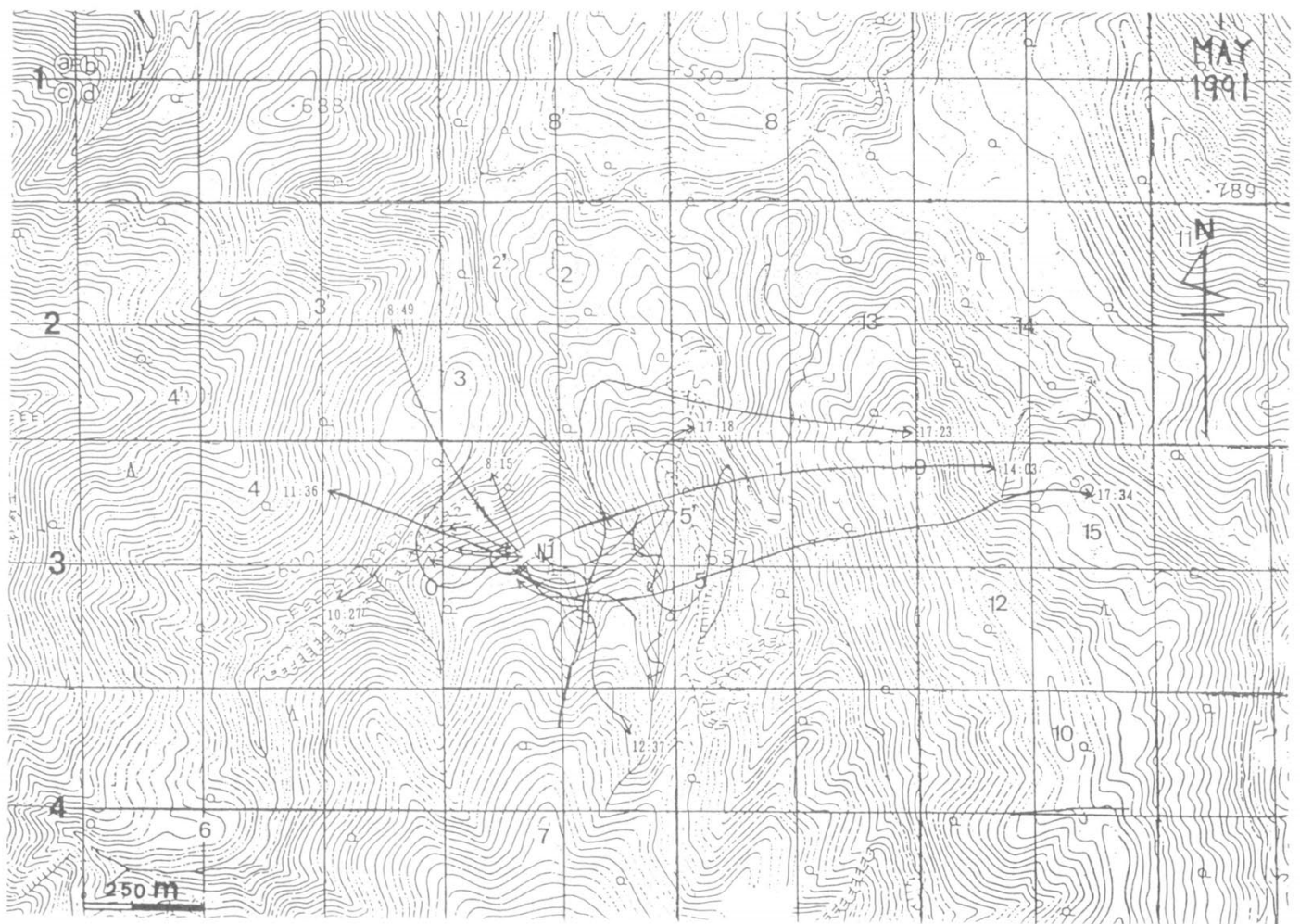

Fig. 3. An example of movement of a female which nested at Mt. Oppu, the Shirakami area, 1991. Solid lines with allow show the movement of female, in May, 1991.

shown in Fig. 3. However, all the breeding activities could not be traced, because of hard angulated topography.

So, it was thought that this activity area of a pair was only a part of the home range. The distribution range of the field signs seemed to show an outline of the home range of this breeding pair. The home range size was estimated to be about 912.5 ha by the mesh method (Fig. 4). Judging from the results obtained at Mt. Moriyoshi and Mt. Oppu, HRS of this species should be about 1,000 ha in the beech forest.

\section{Discussion}

Environment Agency (1976) and Arisawa (1990) reported that HRS of the Black Woodpecker was 300 500 ha in the mixed forest in Hokkaido, while Cramp et al. (1985) reported that the home range of the Black Woodpecker was 870 ha for broad-leaved forest, 650 ha for mixed forest, and 460 ha for coniferous woodland in Europe, and Blume (1973) also reported a similar size in Germany.

HRS of Black Woodpecker in the northern Tohoku District is similar to HRS in broad-leaved forests in Europe reported by Cramp et al. (1985). 


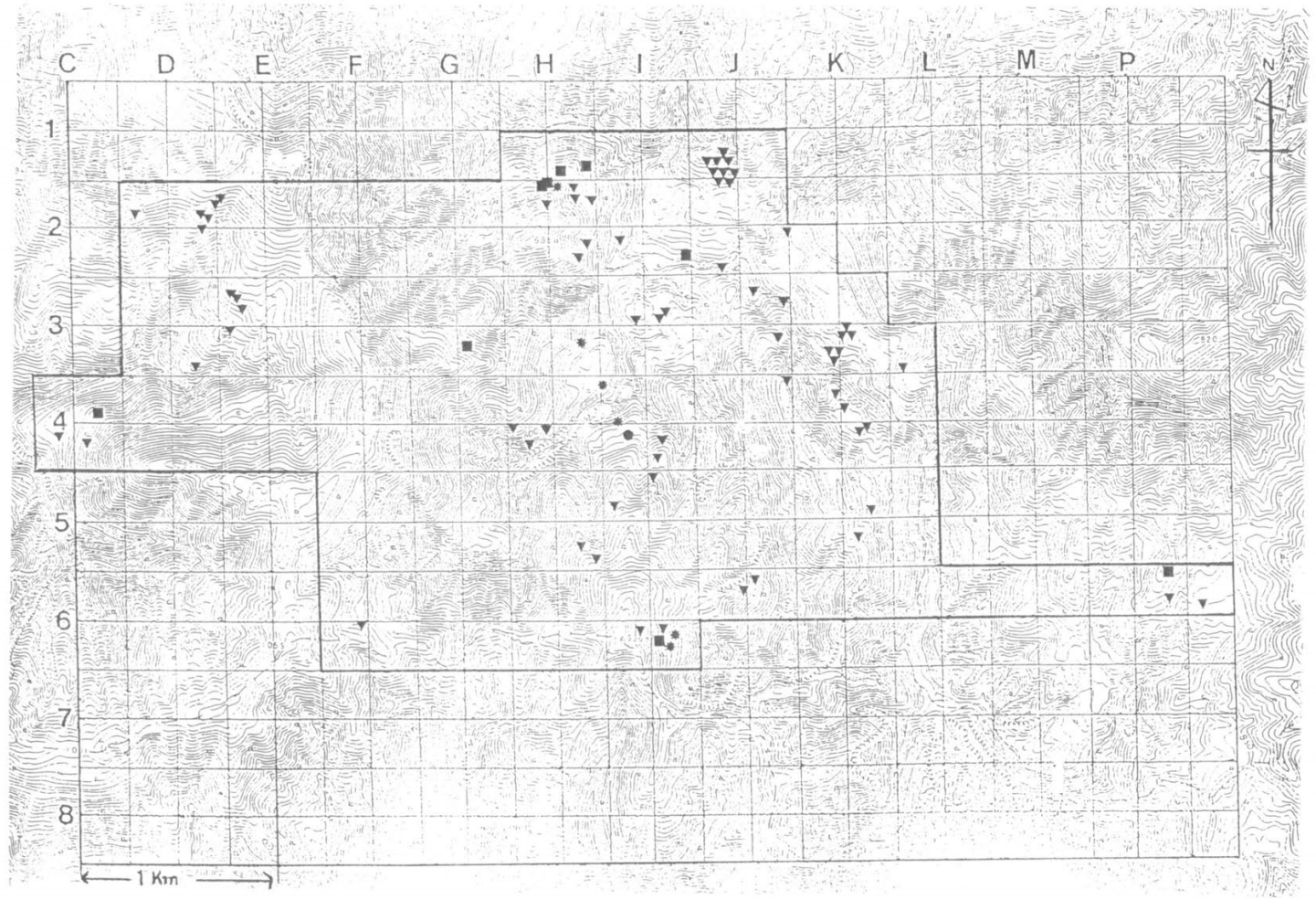

Fig. 4. A distribution map (home range) of the field signs (nesting, roosting, and feeding trees) of Black Woodpecker in the beech forest at Mt. Oppu, the Shirakami area, 1991. Nesting trees

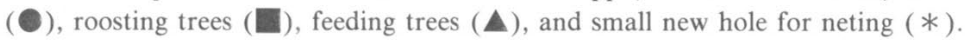

In the present beech forest zone drown by Naito, based on the vegetation map (Environment Agency, 1981) shown in Fig. 5, the following three categories are established; the first was the present beech forest area $(370,600 \mathrm{ha})$, the second was the distribution range (DR) (64,000 ha) in which the occurrence of this species was confirmed by the presence of field signs, and third was the available range (AR) $(23,000 \mathrm{ha})$ in which this species was possibly inhabitable by the evidences of the field signs mentioned above (Table 2).

The home range of a pair of Black Woodpecker which nested in beech forest at Mt. Moriyoshi, from 1978 to 1980 , was not investigated. However, we could recognized a home range of this pair based on the distribution of the field signs as shown in Fig. 2.

As the result, a home range size of this pair was about 1,000 ha in this beech forest.

Furthermore, a home range size of a pair which nested in Mt. Oppu, the Shirakami area, was estimated to be about 912.5 ha. So, we speculated that a home range size of a pair of Black Woodpecker is about 1,000 ha in the beech forest of the northern Tohoku District.

Both areas of DR and AR were about 87,000 ha in total as shown in Table 2. The maximum population size in DR or AR was estimated by dividing DR and AR by HRS 


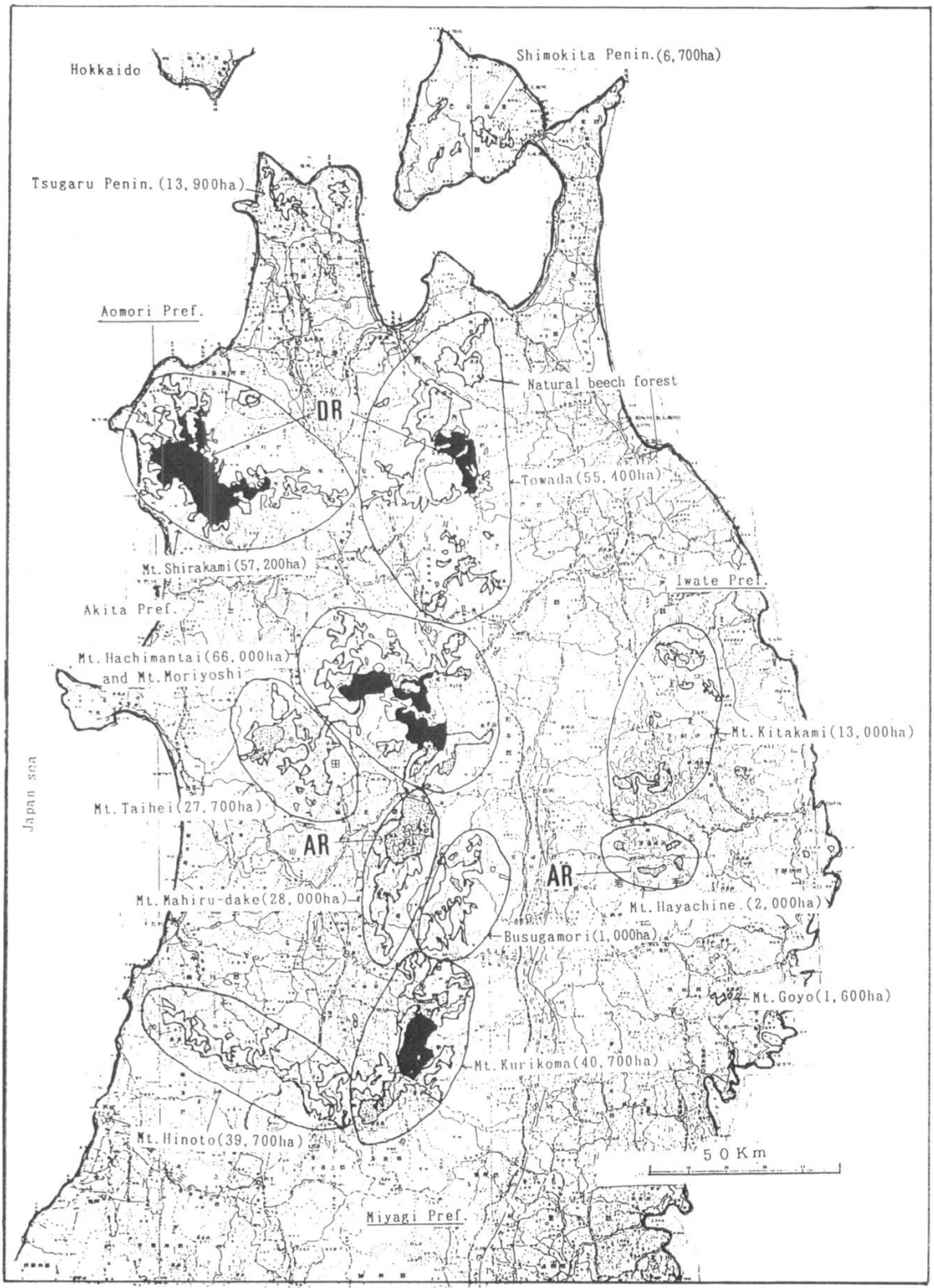

Fig. 5. The distribution map of the natural beech forest and areas of each habitat of Black Woodpeckers in the northern Tohoku District, 1989. Area surrounded by solid line: Natural beech forest. Solid range: Distribution range (DR). Dotted range Available range (AR).

(about 1,000 ha), that is, about 174 birds. These estimated population size may correspond to the carrying capacity of this species in the beech forest zone of the northern Tohoku District. 
The same estimation method was also applied to the Okinawa Woodpecker (Sapheopipo noguchii) by Kuroda (1971) and Ogasawara \& Ikehara (1977).

Almost all of the breeding pairs concentrated in the Shirakami area and Mt. Moriyoshi. However, all of the population are geographically segregated from each other. These situations may be dangerous to conserve this endangered species.

In conclusion, it is important for conservation of the species to enlarge the beech forests or at least to maintain the present beech forest.

\section{Acknowledgments}

We are most grateful to the staff members of Akita Yachono-kai, of the Nature Conservation Society of Japan, and also to Dr. Masatoshi Yui (Tohoku Research Center of Forestry and Forest Products Research Institute) and Prof. Noriaki Nara (Hirosaki Univ.) as chief investigators of Iwate and Aomori Prefectures in the research by the Grant-in-Aid for Co-operative Research (A) in the Ministry of Education, for many kinds of supports to our field studies.

We also thanks to Mr. Koichi Kamada, Mr. Tomio Nagasaki and Mr. Reiichi Sekiya, who provided us some photographs of the Black Woodpecker.

\section{References}

Arisawa, H. 1990. Fundamental ecological study of Black Woodpeckers in the southern limitation in the distribution. General ecology of Black Woodpecker, pp. 5-9. The report of Grant-in-Aid for Co-operative Research (A) in Ministry of Education, Science and Culture (in Japanese).

Environment Agency 1976. A report of the research in the special birds. Black Woodpecker, pp. 33-85.

Blume, D. 1973. Shwarzspecht, Grunspecht, Grauspecht. Die neue Brehm-Bucherei 300, BED WissenschaftsDruch Leipzig GDR.

Cramp, S. Chief ed. 1985. Handbook of the birds of Europe, the Middle, East and North Africa, Vol. 4, Oxford Univ. Press.

Kuroda, N. h. 1971. Natural Monuments of Okinawa; Noguchigera, Animals and Nature (7); 9-10 (in Japanese).

Ogasawara, K. 1988. The World of the Black Woodpecker. Akita Sakigake News Paper Co. LTD. Akita (in Japanese with English summary).

Ogasawara, K. 1990. Fundamental ecological study of Black Woodpeckers in the southern limitation in the distribution. 2. Akita Prefecture. Synthetic discussion. The report of the Grant-in-Aid for Co-operative Research (A) in Ministry of Education, Science and Culture, pp. 19-24 (in Japanese).

Ogasawara, K. \& Ikehara, S. 1977. Ecological and behavioral observations of Okinawa Woodpecker Saphiopipo noguchii, with notes on conservation. Mis. Rept. Yamashina Inst. Ornith. 9; 143-158.

Ogasawara, K. \& Izumi, Y. 1978. Ecological study of Black Woodpecker Dryocopus martius in Fagus crenata forest on Mt. Moriyoshi. Mis. Rept. Yamashina Inst. Ornith. 10; 127-141 (in Japanese with English summary).

Ogasawara, K. \& Izumi, Y. 1980. A report of Scientific research around an area of Komatakyo at Mt. Moriyoshi. General ecology of Black Woodpecker in natural beech forest around an area of Komatakyo. Committee of Education in Akita Prefecture and Scientific Research Group in Komatakyo, pp. 111-130 (in Japanese).

Ohno, M. \& Chiba, S. 1979. Observation of Black Woodpeckers on Towada Lake. National Parks 356; 27 (in Japanese). 
Naito, T. 1990. Fundamental ecological study of Black Woodpeckers in the southern limitation in the distribution. 5. Vegetational research as the inhabitable environment of Black Woodpecker. The report of the Grant-in-Aid for Co-operative Research (A) in Ministry of Education, Science and Culture, pp. 50-53 (in Japanese).

\section{東北北部のクマゲラの生息状況}

クマゲラ (Dryocopus martius) は現在日本では北海道及び東北地方北部にのみ分布し, その一部で繁殖 し,わずかながら子孫を残し続けている。

クマゲラの営巣木, ねぐら木及び採餌木などの調查が; 主に 1989 年, 1990 年に, 東北地方北部（白神山 地, 十和田・八甲田地域, 八幡平, 真昼岳, 毒ヶ森, 栗駒山等) でクマゲラの生活情報のあった地域の成熟 したブナ林で，それぞれ数人の調查員により行なわれた。

クマゲラの行動圈 (HRS) を明かにするため, 1978〜1980 年に森吉山ブナ天然林で繁殖したクマゲラの 営巣木，ねぐら木及び採餌跡を調査し，また 1990〜1992 年に白神山地の尾太岳付近のクマゲラの繁殖行動 を日本自然保護協会の協力で行い，その結果クマゲラの行動圏は両地とも約 1,000 ha と推定された。

東北地方北部の調查地の面積を地図上で計測した結果, 天然ブナ林の総面積は約 370,600 ha であった。 そのうち,クマゲラの生息分布域 (DR) は約 64,000 ha であった。また，ブナ天然林は現在も伐採されつつ あるが, クマゲラの生息可能面積 (AR) は 23,000 ha であり, HRS と DR 及び AR からクマゲラの生息個 体数を推定すると, 約 174 羽であった。

小笠原 景: 秋田大学教育学部生物学研究室 010 秋田市手形学園町 1-1

泉 祐一：秋田県秋田保健所 010 秋田市中通 2-1-52

藤井忠志：津軽石中学校 028-13 岩手県山田町大沢 1-14 